\title{
PEMIKIRAN TEOLOGI DALAM TAFSIR DEPARTEMEN AGAMA
}

\author{
Oleh: Masri Mansoer \\ masri.mansoer@uinjkt.ac.id
}

Abstrak : Islam yang datang ke Nusantara adalah paham teologi Asy ‘ariyah, kental dengan warna Sufisme (Tarikat) dan kurangnya pengaruh paham teologi rasional Teologi Asy ariah semakin berkembang dan menjadi mapan di Indonesia ketika sejumlah ulama yang belajar di Timur Tengah, terutama di Makkah dan Madinah, kembali ke Indonesia sejak abad ke-17 dan 18. Mereka ini, yang secara sosial dan intelektual termasuk ke dalam jaringan ulama di Timur Tengah, yang mempelajari dan mengikuti aliran teologi Asyariah, yang selanjutnya mereka sebarkan melalui kitab-kitab yang mereka tulis. Ulama-ulama besar abad ini seperti Hamzah Fansuri, Ar-Raniri, Abdul Rauf al-Singkili, Al-Maqasri dan Muhammad Nafis Al-Banjari dan Al-Palimbangi adalah pengikut dokrin kalam Asy'ariyah. Namun, hasil yang diperoleh dari penelitian ini adalah Penafsiran terhadap ayat-ayat kalam dalam Tafsir Depag memiliki kecenderungan agak dekat kepada corak pemikiran kalam rasional-Maturidiyah Samarkand. Sebaliknya sedikit sekali persamaannya dengan kalam tradisional (Asy'ariyah dan Maturidiyah Bukhara). Dalam membicarakan kemampuan akal dan fungsi wahyu, ada persamaannya dengan paham kalam Maturidiyah Bukhara, tetapi pendapat dalam Tafsir Depag lebih maju, dimana akal punya potensi mengetahui Tuhan, mengetahui Tuhan itu Esa, mengetahui baik dan buruk, mengetahui dasar adanya kebaikan dan keburukan serta mengetahui adanya kehidupan akhirat.

Kata Kunci : Pemikiran Teologi, Tafsir Departemen Agama, Islam Indonesia

\section{A. Pendahuluan}

Terdapat beberapa teori tentang datangnya Islam ke Nusantara/Indonesia, yaitu: Teori Pertama mengatakan bahwa 
Islam sudah sampai ke Nusantara pada abad pertama hijrah melalui para pedagang Arab, teori kedua Islam datang pada abad ke 13 M melaui pedagang Gujarat dan teori terakhir ke tiga abad ke 13 langsung dari Timur tengah (Hadramaut) oleh para Sufi pengembara.

Menurut Pijnappel, Snouk Hurgronje, Moquette dan umumnya sarjana Belanda berpendapat bahwa Islam datang ke Nusantara berasal dari anak benua India (Gujarat) dibawa oleh para pedagang perantara dari Timur Tengah. Para pedagang ini bermazhab Syafi 'i, hal ini terjadi akhir abad $12 \mathrm{M}$. Mereka ini beralasan dengan kesamaan mazhab orang Gujarat dengan mazhab di Nusantara-mazhab Syafi i dan kesamaan penemuan batu nisan di Barus dan Pasai.

Teori ini dibantah oleh Marison dan TW. Arnold, dikatakan bahwa pada abad 13 M (1297) di Gujarat masih menganut agama Hindu-Budha, kalau Islam berasal dari Gujarat tentu di Gujarat telah kuat Islamnya. Karena itu bagi mereka Islam Nusantara berasal dari Malabar yang dibawa oleh pedagang bermazhab Syafi'i abad 13 dan Malabar bukan satu-satunya asal Islam Nusantara, tapi juga langsung dari Arab abad $7 \mathrm{M}$ yang dibawa oleh para pedagang Arab. Islam berasal dari Arab dan Hadramaut, pada abad ke $7 \mathrm{M}$. pendapat ini didukung oleh Crawfud, Keijzer, Neiman, Hollander, Hamka dan Naquib alAttas.

Azyumardi berpendapat bahwa: 1) Islam datang ke Nusantara langsung dari Arab; 2) Dibawa oleh para guru dan penyiar Profesional; 3) Yang mula-mula masuk Islam adalah para raja dan pengusaha; 4) Kebanyakan penyiar profesional itu datang lebih nyata-massif abad ke 12 dan $13 \mathrm{M}$. AH. Johns mengatakan penyiaran Islam secara insten dan profesional dilakukan oleh para Sufi pengembara abad 13 M. Keberhasilan Sufi ini didukung oleh kemampuan menyajikan Islam dalam kemasan yang atraktif (menyenangkan), harmonis, yang menekankan kesesuaian dengan Islam atau kontinuitas ketimbang perubahan dalam kepercayaan dan praktek keagamaan lokal. Islam datang bukan dengan perang dan intres kekuasaan, ini faktor mudahnya terjadi sinkritisme. 


\section{B. Teologi Islam Indonesia}

Dalam paham teologi, Islam yang datang ke Nusantara adalah paham teologi Asy 'ariyah dan warna Sufisme (Tarikat) dan kurangnya pengaruh paham teologi rasional. Madrasahmadrasah sebagai pusat pengkajian Islam lebih banyak memusatkan pelajarannya pada mata pelajaran Tafsir, Hadis, Hukum (Ushul Fiqh dan Fiqh) dan Kalam. Di banyak Madrasah yang menjadi milik Ahl al-Hadis pelajaran teologi/kalam tidak diajarkan karena dicurigai apalagi paham kalam/teologi rasional (mu`tazilah) yang bukan dianggap Ahl al-Sussnah.

Teologi Asy`ariah semakin berkembang dan menjadi mapan di Indonesia ketika sejumlah ulama yang belajar di Timur Tengah, terutama di Makkah dan Madinah, kembali ke Indonesia sejak abad ke-17 dan 18. Mereka ini, yang secara sosial dan intelektual termasuk ke dalam jaringan ulama di Timur Tengah, yang mempelajari dan mengikuti aliran teologi Asy`ariah, yang selanjutnya mereka sebarkan melalui kitabkitab yang mereka tulis. Ulama-ulama besar abad ini seperti Hamzah Fansuri, Ar-Raniri, Abdul Rauf al-Singkili, Al-Maqasri dan Muhammad Nafis Al-Banjari dan Al-Palimbangi adalah pengikut dokrin kalam Asy'ariyah

Karel A. Steenbrink, dalam penelitiaanya terhadap kitabkitab yang ditemukan dan digunakan di lembaga pendidikan Islam di Indonesia abad $19 \mathrm{M}$ menyimpulkan bahwa kebanyakan kitab-kitab yang digunakan oleh Pesanteren di Nusantara adalah syarah dari kitab-kitab zaman perkembangan pemikiran Islam, dan khusus dalam masalah kalam tidak ditemukan kitab-kitab yang disyarah dari kalangan kalam rasional-mu'tazilah. Kitab-kitab aqidah/teologi yang beredar abad 17,18 dan $19 \mathrm{M}$ adalah berasal dari kitab kalangan teologi Asy'ariyah. Kitab Ushuluddin/kalam yang ditemukan abad $19 \mathrm{M}$ antara lain: Bahjat al-'Ulum karya As-Samarqani, Umm alBarahin (ad-Darrah atau al-Aqa'id al-Sughra) karya As-Sanusi al-Husaini, al-Mufid karya Sulaiman al-Jazuli, Fath al-Mubin karya Muhammad al-Bajuri, Kifayatul al-Awam dan al Miftah fi syarh ma'rifat al-Islam karya Muhammad bin Asy-Syafi'i, Jauharat at-Tauhid dan Iftah al-Murid karya Ibrahim al-Laqani. Kitab Tafsir Jalalain. (Karel A. Steenbrink, h. 157-158) Penulis 
dan Isi kitab ini adalah berpaham kalam Asy`ariyah-tradisonal. Seperti Kitab Bahjat al-'Ulum karya Al-Samarqani: berisi rukun Iman yang enam, konsep iman dan sifat-sifat Tuhan.

Tetapi sejak dekade 70-an dengan banyaknya berdatangan pelajar Indonesia yang telah menyelesaikan studi di luar negeri, terutama Mesir/al-Azhar dari Barat dan kemudian mereka muali memperkenalkan pandangan teologi rasional dan kontekstual dengan berbagai bentuknya. Harun Nasution memperkenalkan dengan Islam Rasionalnya dan Nurcholis Madjid dengan Islam Inklusif dan substansif.

Teologi tradisional menurut Harun Nasution memiliki bebrapa ciri : 1) Kedudukan akal yang rendah; 2) Ketidak bebasan manusia dalam kemauan dan perbuatannya; 3) Kebebasan berpikir yang diikat dengan banyak dogma; 4) Ketidak percayaan kepada sunnatullah dan kausalitas; 5) Terikat kepada arti tekstual dari Al-Qur'an dan Hadis; 6) Statis dalam sikap dan berpikir. Aliran kalam ini diwakili oleh Asy'ariyah dan Muturidiyah Bukhara. (lihat Harun Nasution, Islam Rasional, (Bandung: Mizan, 1996), h. 116).

Teologi rasional atau teologi sunnatullah memiliki ciri : 1) Kedudukan akal yang tinggi; 2) Kebebsan manusia dalam kemauan dan perbuatannya; 3) Kebesan berpikir hanya diikat oleh ajaran dasar dalam Al-Qur'an dan Hadis yang sedikit sekali jumlahnya; 4) Percaya adanya sunnatullah dan kausalitas; 5) Mengambil arti metafor dari teks wahyu; 6) Dinamis dalam sikap berpikir. Aliran kalam ini diwakili oleh Mu'tazilah dan Maturidiyah Samarkan. (Harun Nasution, Islam Rasional, h. 112).

Corak lain pemikiran teologi Islam di Indonesia dapat dikelompokan menjadi: 1) Neo-modernisme, dengan penekanan bahwa Islam harus terlibat dalam pergulatan modernisme diantara tokohnya Nurcholis Madjid; 2) Sosialisme-Demokrasi dengan penekanan pada misi keislaman yang harus memberi makna pada manusia diantara tokohnya M. Dawam Rahardjo dan Adi Sasono; 3) Universalisme (Internasionalisme) yang memberi penekanan pada sifat universal Islam yang memberi diktum tetap diantara tokohnya M. Amin Rais dan A.M. Saifuddin; 4) Modernisme yang penekanannya pada aspek 
rasional dan pembaruan pemikiran Islam yang sesuai dengan kondisi-kondisi modrn diantara tokohnya Harun Nasution dan Djohan Effendi.

Muslim Abdurrahman, mengelompokkan corak teologi di Indonesia kepada : 1) Teologi rasional yang cenderung modernisasi Islam; 2) Teologi hermeneutik yang cenderung untuk Islamisasi 3) Teologi transformatif yang menekankan pada persoalan keadilan dan ketimpangan sosial.

Dari paparan di atas masalah yang ingin dibahas dalam tulisan ini adalah paham teologi Islam Indonesia dengan mengambil focus kajian Tafsir Karya Departemen Agama. Masalah yang dikaji adalah bagaimana corak penafsiran ayatayat kalam yang terdapat dalam kitab Tafsir karya Departemen Agama, khusunya dalam menafsirkan ayat-ayat kalam yang digunakan sebagai dalil oleh para Mutakalimin.

Penelitian ini memusatkan perhatian pada penelitian sejumlah ayat-ayat Al-Qur'an yang dipergunakan sebagai dalil naqli oleh tokoh-tokoh aliran kalam rasional dan tradisional, kemudian dipaparkan penafsirannya menurut Tafsir karya Departemen Agama (Tafsir Depag). Selanjutnya dilakukan analisa perbandingan dengan pendapat aliran kalam rasional dan tradisional untuk menarik kesimpulan tentang paham (aliran kalam) yang terdapat dalam Tafsir Depag.

\section{Menenal Tasfsir Karya Depatemen Agama \\ 1. Riwayat Penulisan}

Penulisan Tafsir ini dibawah Yayasan Penterjemah dan Pentafsir Al-Qur'an Departemen Agama RI dengan Surat Keputusan Menteri Agama RI No. 90 tahun 1972, dan Keputusan Menteri Agama RI No. 8 tahun 1973 yang diketuai oleh Prof. Bustami A. Gani dan Surat Keputusan Agama RI No. 30 tahun 1980: Prof. KH. Ibrahim Husein LML sebagai ketua. ${ }^{3}$ Dari nama-nama anggota tim di atas Prof. Bustami A. Gani, Prof. Dr. Mukhtar Yahya dan KH. Nur Asjik, MA adalah murid langsung dari pengarang tafsir Al-Maraghi-Ahmad Mustafa alMaraghi. ${ }^{4}$ Mungkin ini salah satu pertimbangan dalam pentafsiran ini berpedoman kepada kitab tafsir al-Maraghi. 
Al-Qur'an dan Tafsirnya ini adalah merupakan salah satu proyek pemerintah dalam pembangunan pada sektor agama dengan tujuan:

1. Untuk memudahkan dan menolong umat dalam mempelajari dan memahami ajaran-ajaran agama Islam lebih mendalam dalam rangka mewujudkan cita-cita masyarakat Sosial religius (masyaerakat yang sistem dan nilai sosialnya berdasarkan ajaran agama). ${ }^{5}$

2. supaya Al-Qur'an dapat di pelajari dan dipahami dengan mudah serta diamalkan dalam kehidupan sehari-hari sesuai dengan maksud dan tujuan Al-Qur'an di turunkan sebagai hudan dan rahmat bagi manusia.

3. selain menambah perbendaharaan kitab-kitab keagamaan di dalam negeri juga diharapkan dapat memberikan dorongan yang lebih kuat kepada umat untuk senantiasa meningkatkan pengetahuan, pemahaman dan pengamalan ajaran-ajaran agama dalam rangka ikut berpartisipasi dalam pembangunan.

4. Sebagai kegiatan yang sepenuhnya dibiayai oleh pemerintah RI maka tafsir ini dapat dijadikan Tafsir Standar (yang bercorak mazhab Fiqh tertentu, atau pandangan kalam tertentu atau aliran tasawuf/tarikat terentu), yang hanya mencoba menjelaskan secara sederhana maksud dan tujuan dari ayat-ayat Al-Qur'an yang sudah diterjemahkan dalam Al-Qur'an dan Terjemahannya. ${ }^{6}$

\section{Metode dan Sumber}

Metode (cara) menafsirkan kitab Tafsir ini mengikuti prosedur sebagi berikut : memperhatikan hadist-hadist Nabi terutama mengenai sebab-sebab turunnya ayat-ayat, kemudian memperhatikan pendapat-pendapat para sahabat mengenai penjelasan dan maksud dari ayat-ayat al-Qur'an yang ditafsirkan. Selanjutnya diperhatikan pula pendapat para tabi'in dan pendapat para mufassir yang telah menafsirkan al-Qur'an berdasarkan hadist, ucapan dan pendapat sahabat. Selain itu juga diperhatikan ayat-ayat dengan ayat lain, sebab dalam al-Qur'an kadang kala satu atau beberapa ayat dijelaskan atau ditafsirkan oleh ayat lainnya. ${ }^{1}$ 
Penulisan Tafsir ini tidak mengarahkan kepada kecenderungan (corak) tertentu dan tidak pula untuk membahas berbagai masalah dan kecenderungan. Tetapi hanya akan menyusun tafsir standar untuk menjelaskan dengan cara sederhana maksud dan tujuan dari ayat-ayat yang telah diterjemahkan dalam al-Qur'an dan Terjemahnya. Sebagai sumber penafsiran dimaksud, maka akan ditelaah dan diseleksi kitab-kitab tafsir yang telah ada sejauh ada kaitannya dengan ayat-ayat dalam masalah yang ditafsirkan, sumber utama ditelaah berbagai kitab tafsir seperti :

1. Kitab Tafsir Al-Marghi oleh Ahmad Mustafa al-Marghi

2. Tafsir Mahasimut Ta'wil oleh Al-Qasimi

3. Kitab Tafsir Anwa al-Tanzil wa Asrar al-Ta'wil oleh AlBaidlawi

4. Kitab Tafsir al-Qur'an al-Azhim oleh Ibn Katsir

Selain kitab-kitab tafsir ini juga ditelaah kitab tafsir lain seperti kitab tafsir Fil Zhilali al-Qur'an karya Sayyid Quthub, tafsir Al-Manar karya Rasyid Ridha, Ruh al-Ma'ani fi Tafsir alQur'an wa al-sab'u al-Matsani karya Al-Alusi, Al-Tafsir alWadhh karya Muhammad al-Hijazi dan tafsir AL-Jami' li ahkam al-Qur'an karya Qurthubi. ${ }^{2}$

Keseluruhan kitab tafsir yang dijadikan rujukan di atas adalah tafsir dengan metode tahlili ${ }^{3}$ dengan kecenderungan yang berbeda. Tafsir al-Maraghi (W.1945) ${ }^{4}$, tafsir al-Manar karya Rasyid Ridha (W. 1935), tafsir Sayyid Qutub(W.1966), ${ }^{5}$ tafsir al-Waadlih karya Muhammad Mahmud Hijaz dengan kecenderungan al-Adabi al Ijtima ${ }^{i}{ }^{6}{ }^{6}$ dan tafsir al-Qasimi (W. 1914) ${ }^{7}$ dengan sistematika yang luas (Ithnab) dan semua tafsir ini termasuk tafsir periode modern. Tafsir Qurtubi (W. $671 \mathrm{H}$ ) adalah tafsir Tahlili dengan corak fiqh (hukum) yang amat luas kajiannya dengan mengedepankan masalah khilafiyah dan dalildalil setiap pendapat serta mengkomentari, walaupun ia mewakili tafsir fiqh kalangan Maliki, tetapi ia fanatik terhadap mahzabnya. ${ }^{8}$ Tafsir al-Baidlawi (W. $\left.691 \mathrm{H}\right)^{9}$ dan Al-Alusi (W. $1271 \mathrm{H}$ ) adalah tafsir bi al-Ra'yi (al-Dirayah). Dari sudut fiqh tafsir al-Alusi termasuk pembela mahzab Hanafiyah ${ }^{10}$. Tafsir Ibn Katsir (W. $774 \mathrm{H}$ ) adalah tafsir bi al-Ma'tsur dengan 
kecenderungan kalam (corak keagamaan) Asy'ariyah dan dalam fiqh termasuk tafsir mahzab Syafi'iyah. ${ }^{11}$

Berdasarkan penelitian penulis dengan membandingkan kitab-kitab tafsir yang dijadikan rujukan oleh Tafsir Depag, maka metode tafsir yang dignakan dilihat dari sei sumber penafsiran, maka tafsir ini termasuk tafsir bil-Izdliwaji (campuran) antara metode bi al-Ma'tsur (Riwayah) dan bi alRa'yi (Dirayah) dan dilihat dari segi tertib ayat termasuk metode tafsir Tahlili, dan dari segi corak (kecenderungan) adalah alAdabai al-Ijtima’i.

\section{Sistematika atau Teknik}

Sistematika yang digunakan dalam tafsir ini adalah pertamatama mengemukakan mukadimah dari surat yang akan ditafsirkan, yang berisikan tentang penamaan surat, jumlah ayat, tempat turun surat, isi-isi pokok dalam surat serta munasabah surat dengan surat sebelumnya. Kemudian memaparkan pokok/topik masalah (bahasan) yang akan dibahas, setelah itu mengutip satu atau beberapa ayat yang akan ditafsirkan dengan disertakan terjemahnya. Selanjutnya disusun tafsirnya dengan menyebut munasabah (hubungan ayat dengan ayat sebelumnya). Bila ada riwayat atau hadis yang menjelaskan tentang sebabsebab turunnya ayat/surat dikutip hadis tersebut. Dalam tafsir ini tidak ada arti kosa kata, arti global tapi langsung saja menafsir ayat demi ayat dengan gaya bahasa yang mudah dipahami. Kalau ada perbedaan pendapat ulama tafsir tentang masalah yang dibahas dalam ayat tersebut, diambil pendapat Jumhur Ulama dan dicantumkan dalam catatan kaki pendapat ulama lainnya.

Setelah penafsiran dipandang cukup memadai pembahasannya, kemudian dibuat kesimpulan secara pointerpointer untuk memudahkan pengertian dan pemahaman oleh pembaca.

Tafsir Departemen Agama ini berjumlah 10 jilid. Setiap jilid terdiri dari 3 juz, dan 1 jilid Muqadimah al-Qur'an dan Tafsirnya untuk memperkenalkan kepada pembaca tentang pengertian al-Qur'an, tafsir dan sebagainya. 
Untuk memudahkan pembaca mencari pokok masalah yang akan diketahui dalam daftar isi setiap jilidnya terdapat pokokpokok bahasan yang dibicarakan. Dan pada jilid terakhir dicantumkan daftar kepustakaan untuk menambah wawasan bagi pembaca yang ingin mengetahui masalah tafisr lebih banyak. Karena itu sistematika atau teknik (keluasan pembahasan) penulisan Tafsir ini termasuk teknik penulisan alManhaj al-Wasith (sedang, tidak terlalu luas atau ithnabi dan tidak pula terlalu singakt ijazi) ${ }^{12}$ dengan fokus (titik berat penjelasan) pada maksud dan tujuan ayat-ayat yang ditafsirkan. Dan kitab tafsir ini termasuk tafsir al-Jama i pertama di dunia Islam.

\section{Klaksifikasi Ayat-Ayat Kalam}

\section{A. Akal dan Fungsi Wahyu}

Mu'tazilah berpendapat bahwa semua pengetahuan tentang adanya Tuhan mengetahui yang baik dan buruk dapat diperoleh dengan perantara akal, dan kewajiban-kewajibannya dapat diketahui dengan pemikiran yang mendalam. Dengan kata lain semua pengetahuan dan kewajiban di atas sebelum ada turunnya wahyu dapat diketahui oleh akal. ${ }^{13}$ Bagi Maturidiyah Samarkand, selain kewajiban mengerjakan yang baik dan menjauhi yang buruk dapat diketahui melalui akal. Ayat-ayat yang dijadikan dalil adalah sebagai berikut : surat Hud (11) : 24, surat Fushshilat (41) : 53, surat al-Ghasyiyah (88) : 17 dan alAraf (7) 185. Sebagai contoh:

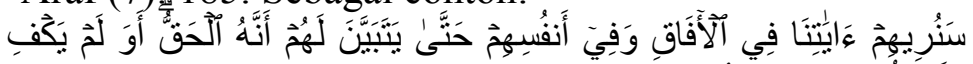

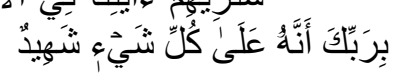

Kami akan memperlihatkan kepada mereka tanda-tanda (kekuasaan) Kami disegenap ufuk dan pada diri mereka sendiri sehingga jelas bagi mereka bahwa al Qur'an itu adalah benar. (QS. Fushshilat 41: 53) ${ }^{14}$

Tiga ayat terakhir dari ayat-ayat di atas mengisyaratkan bahwa Allah telah mewajibkan perenungan dan pemikiran mendalam terhadap ciptaan-Nya agar diketahui bahwa Dia Maha Pencipta. Ini berarti bahwa ayat-ayat tersebut menunjukan bukti wajib berterima kasih kepada Allah sebelum ada turunnya wahyu. Manusia dengan kemampuan akalnya dapat mengetahui 
bahwa kekufuran itu adalah haram, sebab kekufuran itu sesuatu yang dibenci oleh Allah. Oleh karena itu dengan kemampuan akalnya manusia di manapun mengetahui bahwa berterima kasih kepada Allah itu adalah wajib. ${ }^{15}$

Paham Asy'ariyah berpendapat mengetahui Tuhan dapat diperoleh melalui akal, mengatahuai yang baik dan buruk, kewajiban berterimakasih kepada Tuhan kewajiban mengerjakan yang baik dan meninggalkan yang buruk diketahui hanya melalui wahyu. Sedangkan Maturidiyah Bukhara berpendapat semua pengetahuan dapat diketahui melalui akal dan kewajibankewajiban diketahui melalui wahyu. ${ }^{16}$ Ayat-ayat al Qur'an yang dijadikan dalil adalah sebagai berikut: surat al-Isra' (17): 15, surat Thaha (20): 134, surat al-Anisa (4) 165 dan surat al-Mulk (67) 8-9, sebagai contoh :

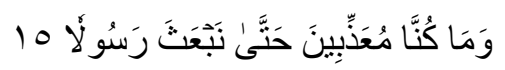

Dan Kami tidak mengazab sebelum Kami mengutus seorang Rasul (QS. Al-Isra', 17:15) ${ }^{17}$

Ayat-ayat diatas menjelaskan bahwa Allah tidak akan memberikan ganjaran pahala atau siksa atas perbuatan manusia yang baik dan buruk kecuali setelah diutus Nabi dan Rasul. Oleh sebab itu segala sesuatu yang berkaitan dengan agama hanya bisa diketahui manusia dengan perantara Nabi dan Rasul Allah, tidak dengan akalnya semata-mata. Kewajiban-kewajiban baru ada setelah diberitahukan oleh Allah melalui wahyu-Nya. Keimanan dan kekufuran tidak dapat diketahui kecuali dengan pengirimnan seorang Rasul yang diutus oleh Allah, demikian pula kewajiban-kewajiban tidaklah tergambarkan kecuali setelah diutusnya Rasul yang menyampaikan wahyu-Nya.

Ditemukan dalam Tafsir Depag bahwa akal adalah salah satu dari empat hidayah yang diberikan oleh Allah kepada manusia (naluri, panca indra, akal dan agama). Dia memiliki kemampuan untuk: 1) Menyalurkan naluri ke arah yang baik agar dapat menjadi dasar (pokok) bagi kebaikan; 2) Membetulkan (mengoreksi) kesalahan-kesalahan yang didapat dari panca indra; 3) Membedakan yang baik dengan yang buruk; 4) Menyusun mukadimah untuk sampai kepada natijah; 5) Mengetahui kausalitas; 6) Menggunakan yang mahsusat sebagai tangga untuk sampai kepada yang ma'qulat; 7) Mempergunakan 
yang indrawi untuk sampai kepada yang abstrak, maknawai dan ghaib; 8) Mengambil dalil dari adanya makhluk untuk menyimpulkan adanya khalik (Tuhan), yang menciptakan dan menganugrahkan kepada ciptaan-Nya segala sesuatu yang dibutuhkan untuk memelihara dan melangsungkan kehidupannya. $^{18}$

Dengan kemapuan akal itu juga manusia dapat mencoba memikirkan bagaimana cara berterima kasih kepada Tuhan, bahkan sampai kepada keyakinan tentang ke-Esa-an Tuhan (tauhid), dan keyakinan tauhidi ini adalah sesuai dengan naluri manusia. ${ }^{19}$ Dengan mengamati alam nyata ini manusia dengan akalnya juga dapat sampai kepada kesimpulan akan adanya kehidupan akhirat yang kekal dan abadi sebagai tempat pembalasan atas semua perbuatan manusia yang seadil-adilnya, bukan saja suatu hal yang ditetapkan melalui agama tapi juga dapat dibuktikan dengan akal. ${ }^{20}$

Sedangkan ayat 17 surat al-Ghasyiyah substansinya adalah pertanyaan Allah kepada orang-orang musyrik yang mengingkari tentang hari kebangkitan, kepada mereka dipertanyakan oleh Allah apakah mereka tidak memperhatikan bagaimana realitas empiris di sekitarnya - Unta yang akrab dengan kehidupan mereka sehari-hari. Seandainya mereka memperhatikan dengan penuh ketelitian (mempergunakan pancaindra dan perenungan), maka tentu mereka akan mengakui ada penciptanya (Tuhan) yang dapat membangkitakan manusia di hari akhirat nanti. ${ }^{21}$

Ayat 165 surat al-Nisa' menginformasikan bahwa tidak ada satu umat pun yang tidak diturunkan kepada mereka rasul untuk menyampaikan wahyu (syari'at), baik yang dikisahkan dalam alQur'an ataupun yang tidak dikisahkan. Seperti ada yang diutus di negeri Jepang, Cina, India, Eropa dan Amerika. Hal ini dimaksudkan agar tidak ada lagi nanti di akhirat alasan (hujah) bagi orang kafir untuk menyalahkan Allah bahwa kepada mereka tidak datang pemberi peringatan, karena itulah mereka menjadi kafir. ${ }^{22}$ Dalam ayat 15 al-Isra' lebih ditegaskan lagi bahwa perintah dan larang itu atas dasar syari'at dan tuntunan Rasul. Barang siapa yang menyimpang dari itu berarti ia telah menyesatkan (menyia-nyiakan) dirinya. Karena itu tak ada taklif 
(pembebanan hukum) kecuali setelah datangnya wahyu (syari'at). ${ }^{23}$

Dari beberapa kutipan penafsiran terhadap ayat-ayat yang dijadikan dalil oleh kalam rasional dan tradisional dapat ditarik kesimpulan, bahwa penafsiran yang terdapat dalam Tafsir Depag tidak ada indikasi (petunjuk) secara eksplisit kewajiban manusia untuk mengetahui Tuhan, melakukan yang baik dan menjauhi yang buruk, kecuali mengajak manusia khusus yang kafir mempergunakan penglihatan, pendengaran, akalnya untuk memperhatikan dan memikirkan ayat-ayat qauniyah (alam) dan qur'aniyah agar mempercayai (meyakini) adanya Tuhan dan kerasulan Muhammad Saw dengan kebenaran ajaran yang dibawanya. Adanya perintah, larangan, pahala, dan siksa (kewajiban-kewajiban) setelah diutusnya para Rasul pembawa syari'at.

Dalam hal kemampuan akal yang ditemukan dalam Kitab Tafsir Depag disimpulkan ada persamaan dengan aliran kalam Maturidiyah Bukhara, dimana akal punya kemampuan mengetahui Tuhan, mengetahui baik dan buruk, dan mengetahui adanya sebab kewajiban menjadi wajib. Tetapi dalam Tafsir Depag lebih maju memposisikan akal, dimana selain mengetahui Tuhan, mengetahui baik dan buruk mengetahui sebab kebaikan menjadi wajib, dan sebab keburukan menjadi larangan adalah mengetahui Tuhan Esa dan akan adanya kehidupan akhirat (kebangkitan).

\section{B. Fungsi Wahyu}

Kelanjutan dari masalah kemampuan akal dan wahyu adalah mengenai fungsi wahyu. Menurut Mu'tazilah dan Maturidiyah Samarkand wahyu berfungsi memberikan konfirmasi dan informasi tentang apa yang telah diketahui atau didapat oleh akal sebelumnya. Fungsi konfirmasi dalam arti apa yang sudah diketahui dan didaptkan oleh akal wahyu memperkuatnya. Sedangkan fungsi informasi adalah memerinci dan memberitahukan apa yang belum dicapai oleh akal. Tetapi walaupun demikian tidak berarti wahyu tidak penting, bagi mereka wahyu tetap perlu dalam memberitahukan bagaimana cara berterima kasih pada Tuhan, menyempurnakan 
pengetahuan tentang yang baik dan buruk serta menjelaskan perincian tentang upah/pahala dan hukuman yang akan diterima manusia di akhirat nanti. ${ }^{24}$

Sementara itu bagi kalangan teolog tradisional fungsi wahyu amat besar, tanpa wahyu manusia tidak akan tahu mana yang baik dan mana yang buruk, dan tidak akan tahu apa-apa yang menjadi kewajibannya. Bahkan tidak akan diperhitungkan di akhirat nanti tentang aapa saja yang telah dia lakukan. ${ }^{25}$ Ayatayat al Qur'an yang khusus dijadikan dalil untuk mendukung pendapat dari kedua kelompok ini (rasional dan tradisional) sepengetahuan penulis sama ayat-ayat al Qur'an tentang fungsi akal dan wahyu.

Dalam Tafsir Depag Akal mempunyai keterbatasan untuk mengetahui : cara yang benar berterima kasih pada Allah; ${ }^{26}$ kepastian dan betul-betul balasan di akhirat nanti, ${ }^{27}$ cara dan jalan yang benar untuk kebahagiaan di dunia, maka diutuslah oleh Allah rasul-rasul untuk membawa agama yang akan menyampaikan kepada manusia jalan yang harus mereka tempuh untuk kebahagiaan mereka di dunia dan akhirat. ${ }^{28}$ Karena itu, wahyu (agama) menjadi pedoman hidup manusia dalam masalah-masalah keyakinan (aqidah) dan syari'ah (hukum-hukum) serta peraturan-peraturan hidup lainnya. ${ }^{29}$

Wahyu selain berisikan pokok agama, norma-norma, hikmah-hikmah, petunjuk untuk mendapatkan jalan kebahagiaan manusia di dunia dan akhirat. Kebahagiaan makhluk pada umumnya, dia juga mengandung pengetahuan tentang berita-berita yang ghaib, masa lampau, masa sekarang dan masa yang akan datang. ${ }^{30}$ Bahkan, para Nabi, apalagi umatnya, tidak mengetahui perincian syari'at dan tandatandanya sebelum turun wahyu. Demikian ketika memberi pendapat tentang fungsi wahyu dalam Surat Al-Ayura (42) ayat 52

Dari kutipan di atas dapat disimpulkan, meskipun tidak secara langsung (eksplisit) dalam Tafsir Depag fungsi wahyu adalah sebagai sumber informasi, namun dengan mengatakan bahwa wahyu adalah pengetahuan yang diterima oleh para Nabi dari Tuhan sebagai Wujud kalam Allah dan tidak diusahakan (diikhtiarkan) untuk mendapatkannya, ini berarti waahyu itu 
sumber informasi yang sangat tergantung kepada siapa yang dipilih-Nya untuk diturunkan kepadanya. Sejalan dengan itu, berarti pula untuk diturunkan atau tidak diturunkannya wahyu atau agama kepada para Rasul adalah hak prerogatif Allah.

\section{Free Will dan Predestination}

Free will dan Predestination ini adalah faham teologi yang membincan apakah manusia memiliki kebebasan dalam berkehendak dan berbuat untuk mewujudkan perbuatannya atau dalam keadaan terpaksa (fatalisme).

Bagi pahamMu'tazilah manusia memiliki kebebasan dan kuasa dalam mewujudkan perbuatannya. Tuhan memberikan daya (potensi) sebelumnya dan dialah berdasarkan kebebasannya mempergunakan daya dalam mewujudkan perbuatan-perbuatannya. Karena itu perbuatan manusia adalah perbuatannya sendiri secara hakiki. Maturidiyah Samarkand membagi perbuatan kepada perbuatan Tuhan dan perbuatan manusia. Perbuatan Tuhan mangambil bentuk penciptaan daya (al-istitha'ah) dalam diri manusia dan penggunaan daya itu adalah perbuatan manusia dan manusia diberi kebebasan dalam mewujudkan perbuatannya. Karena itu perbuatan manusia adalah perbuatannya dalam artian sesungguhnya bukan dalam arti kiasan. Ayat-ayat al Qur'an yang digunakan sebagai dalil dalam hal ini adalah sebagai berikut: surat Ali Imran (3) 133, surat al-Anisa' (4) 79, surat al-Baqarau (2) 108, al-Ahqaf: 46, alTaubah (9) : 82, surat al-Kahfi (18) : 29, surat al-Thaghabun (64) : 2, sebaai contoh : ${ }^{31}$

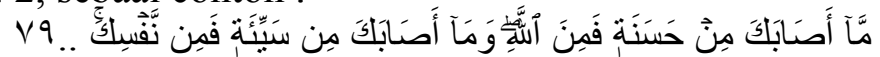

Apa saja nikmat yang kamu peroleh adalah dari Allah, dan apa saja bencana yang menimpamu, maka dari (kesalahan) dirimu sendiri (QS. Al-Nisa',4:79) ${ }^{32}$

Surat al-Nisa' ayat 79 dan al-Baqarah ayat 108 menggambarkan bahwa manusia sendirilah yang melakukan perbuatannya, bukan Tuhan. Seperti melakukan perbuatan jahat dan menukar iman dengan kekafiran, kalau bukan manusia yang melakukan tentu dinisbahkan kepada Tuhan perbuatan itu, bukan kepada manusia tapi ternyata dinisbahkan kepada manusia, demikian Qadhi Abd al-Jabbar. ${ }^{33}$ 
Sementara kalangan teolog Asy'ariyah menampilkan konsep al-Kasb dalam menyelesaikan masalah free will dan predestination (Qadariyah dan Jabariyah). Bagi Asy'ari sendiri arti kata iktisab yaitu sesuatu terjadi karena daya yang diciptakan dan dengan demikian menjadi perolehan atau kasb bagi orang yang dengannya perbuatan itu timbul. Dalam alLuma Asy'ari mengartikan kata al-Kasb ialah bahwa sesuatu timbul dari al-muktasib (yang memperoleh) dengan perantara daya yang telah diciptakan. Term diciptakan dan memperoleh mengandung arti kompromi antara kelemahan manusia dan kekuasaan mutlak Tuhan dan pertanggung jawaban manusia atas perbuatannya, sedangkan kasb itu sendiri diciptakan Tuhan, akhirnya manusia pasif dalam perbuatannya. Dengan demikian perbuatan manusia diciptakan Tuhan dan tidak ada pembuat (faa'il) bagi kasb kecuali Tuhan, dengan demikian perbuatan manusia pada hakekatnya adalah perbuatan Tuhan sendiri. ${ }^{34}$ Ayat-ayat al Qur'an yang dijadikan dalil untuk mendukung pendapat ini adalah : surat al- Shafat (37): 96, surat al-Insan (76): 30:

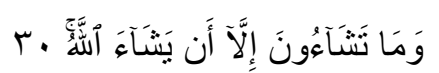

Dan kamu tidak menghendaki, kecuali A llah menghendaki (QS. Al-Insan, 76: 30) 35

Al-A'sya'ari memahami kata wa mâ ta'malûn dalam ayat 96 surat al-Shafat dengan apa yang kamu perbuat, bukan apa yang kamu buat. Dengan demikian ayat itu mengandung arti Allah menciptakan kamu dan perbuatan-perbuatan kamu. ${ }^{36}$ Ayat 30 surat al-Insan diartikan bahwa manusia tidak bisa menghendaki sesuatu, kecuali jika Allah menghendaki sesuatu itu.

Maturidiyah Bukhara sepaham dengan Maturidiyah Samarkand tentang adanya dua daya dalam diri manusia, tetapi berbeda ketika mengatakan bahwa manusia tidak punya daya untuk mencipta. Daya yang ada pada diri manusia hanya untuk menjadikan manusia mampu melakukan perbuatannya. Dalam hal ini yang pencipta hanya Tuhan termasuk menciptakan perbuatan manusia. Ini berarti manusia hanya dapat melakukan perbuatan yang telah diciptakan Tuhan bagi dirinya. ${ }^{37}$ Ayat-ayat al-Qur'an yang dijadikan sebagai dalil adalah surat al-Mulk (67) 
: 13-14, surat al-Rum (30) : 22 dan surat al-Ra`du (13) : 16 sebaai contoh :

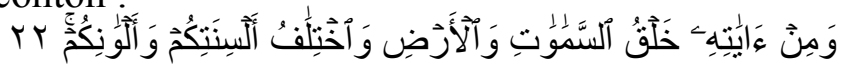

Dan diantara tanda-tanda kekuasaan-Nya ialah menciptakan langit dan bumi dan berlain-lainan bahasa dan warna kulitmu. (QS Al-Rum, 30:22)

Surat al-Mulk ayat 13-14 di atas dipahami oleh Al-Bazdawi bahwa segala sesuatu, termasuk perbuatan manusia adalah ciptaan Allah, seperti ucapan manusia berbisik ataupun berbicara secara keras. Ayat 22 surat al-Rum juga mempertegas bahwa perbedaan bahasa dan warna kulit juga diciptakan oleh Allah. Ini berarti ucapan yang merupakan perbuatan manusia juga ciptaan Allah. Kata al-khalq dalam surat al-Ra'du ayat 16 bagi Al-Bazdawi adalah al-fi'il (perbuatan) dan al-sun'u (buatan). Oleh sebab itu segala sesuatu yang terjadi di langit dan di bumi merupakan ciptaan Allah, dalam arti perbuatan dan buatan Allah. ${ }^{38}$

Dalam Tafsir Depag ayat 79 surat al-Nisa' ditafsirkan bahwa sesuatu yang baik itu datangnya dari Allah dan malapetaka atau kegagalan yang menimpa seseorang itu datang dari dirinya sendiri, yang mungkin diakibatkan oleh kelalaiannya atau kelalaian orang lain, mungkin saudara atau teman. $^{39}$ Manusia memiliki kebebasan untuk memilih antara mau beriman atau kafir, antara mau melakukan kebaikan atau kejahatan. Hal ini dapat difahami ketika menafsirkan Ssurat alKahfi (18) : 29

"Manfaat dari kebenaran itu kembali kepada mereka yang mengamalkannya, sebaliknya akibat buruk dari pengingkaran terhadap kebenaran, kembali kepada mereka yang ingkar. Oleh sebab itu siapa yang ingin beriman hendaklah ia segera berbuat tapi kalau manusia itu memilih kekafiran dari iman atau melepas iman mengambil kekafiran berarti ia telah melakukan kezaliman, yakni telah meletakkan sesuatu tidak pada tempatnya. Sebab itu Allah memberi ancaman keras dengan melemparkan mereka ke neraka". 40

Dari paparan di atas dapat dipahami kearah mana kecenderungan penafsiran Tafsir Depag dalam masalah Qadariyah (free will) dan Jabariyah (predestination). Secara 
eksplisit memang tidak ditemukan bahwa daya, kemauan dan perbuatan adalah diciptakan oleh manusia. Tetapi tidak pula ditemukan bahwa kemauan dan daya manusia dalam mewujudkan perbuatannya diciptakan Allah seperti yang dipahami dari aliran Jabariyah. Dengan mengatakan bahwa manusia mempunyai ikhtiar (daya untuk memilih) dan kebebasan untuk melakukan (mewujudkan suatu perbuatan atau tidak melakukan), dan dengan mengatakan kaya atau miskin bukanlah nasib manusia melainkan itu adalah sunatullah atau adanya rangkaian causalitas untuk mencapai kebaikan dan kesesatan. Maka dapat dikatakan Tafsir Depag ini agak dekat ke paham Qadariyah ketimbang Jabariyah dalam menafsirkan ayat-ayat di atas.

Jadi seseorang yang mau beriman atau kafir bukan kehendak Allah tetapi pilihan manusia, kaya atau miskin bukan takdir (nasib) melainkan usaha dan kemampuannya mengetahui dan menggunakan sunnatullah. Oleh karena itu corak teologi tafsir ini dalam hal menafsirkan ayat-ayat tentang kebebasan kehenddak dan berbuat mendekati paham teologi rasional.

Tafsir Depag ini member apresiasi terhadap ikhtiar, kebebasan dan causalitas dapat juga dipahami dalam menafsirkan surat al-Ra'd (13) : 27, al-Nahl(16): 93 dan fathir (35): 8 .

\section{E. Kekuasaan dan Kehendak Mutlak Tuhan}

Persoalan kekuasaan dan kehendak mutlak Tuhan terkait dengan kebebasan manusia, sunnatullah (hukum-hukum alam yang diciptakan Allah bagi mahluk-Nya), janji dan ancaman Allah yang dapat menjadikan kekuasaan dan kehendak mutlak Tuhan tidak lagi menjadi mutlak (terbatas). Dengan kata lain kekeuasaan dan kehendak Tuhan dibatasi oleh Tuhan sendiri bukan oleh yang selain diri-Nya, hal ini sebagai tanda (indikasi) keadilan Tuhan. Ayat al-Qur'an yang dijadikan dalil oleh Mu'tazilah adalah :

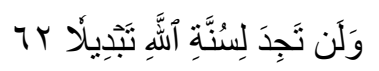

Dan sekali-kali kamu tidak akan mendapati perubahan pada sunnah Allah (QS. Al-Ahzab, $33: 62){ }^{41}$ 
Ayat di atas, seperti yang dikatakan oleh al-Jahiz dipahami bahwa benda-benda memiliki natur dan hukum alamnya masingmasing dan akan menimbulkan efek atau akibat sesuai dengan naturnya itu. Dan natur itu tidak mengalami perubahan atas kehendak Tuhan, maka kalau tidak demikian tidak ada kepastian dalam sunnah Allah atas ciptaan-Nya. ${ }^{42}$ Karena itulah kekuasaan dan kehendak mutlak Tuhan terbatas oleh kekuasaan dan kehendak yang diciptakan-Nya sendiri.

Para teolog Maturidiyah Samarkand berpendapat bahwa kekuasaan dan kehendak mutlak Tuhan hanya dibatasi pada kemerdekaan (kebebasan) manusia, keadaan Tuhan tidak menjatuhkan hukuman secara sewenang-wenang kepada manusia dan keadaan Tuhan mesti menepati janjinya nanti di akhirat. ${ }^{43}$ Ayat-ayat al-Qur'an yang dijadikan sandaran adalah : surat al-Maidah (4) : 48, surat al-An`am (6) 149 dan surat Yunus (10) : 99 sebagai contoh:

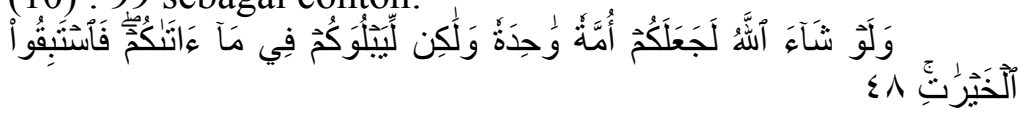

Sekiranya Allah menghendaki, niscaya kamu dijadikan-Nya satu umat saja, tetapi Allah hendak menguji kamu terhadap pemberian-Nya kepada kamu, maka berlomba-lombalah berbuat kebajikan (QS. Al-Ma'idah, 5:48) ${ }^{44}$

Ayat-ayat di atas dipahami oleh aliran Maturidiyah Samarkan bahwa sebenarnya Allah berkuasa untuk membuat manusia beriman seluruhnya, tetapi Allah tidak melaksanakan itu disebabkan Allah memberikan kemerdekaan dan kemauan kepada manusia untuk memilih dan berbuat untuk menjadi orang beriman atau tidak beriman.

Bagi aliran Asy'ariyah dan Maturidiyah Bukhara Tuhan memiliki kekuasaan dan kehendak mutlak, sebab Tuhan adalah Maha Pemilik (al-Malik) yang bersifat mutlak (absolut) dan berbuat apa saja yang dikehendaki-Nya dalam kerajaan-Nya dan tidak ada seorangpun yang dapat mencela apapun perbuatanNya, walaupun dipandang akal manusia tidak adil. ${ }^{45}$ Ayat-ayat yang dijadikan dalil dalam mendukung pendapat mereka adalah : surat al-Buruj (85): 16, surat Yunus (10): 99, surat al-Sajadah (32): 13, surat al-An`am (6): 112 dan al-Baqarah (2) 253), sebagai contoh: 


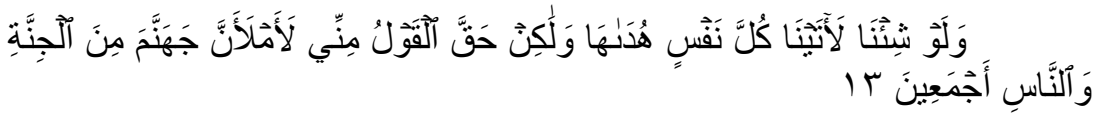

Dan kalau Kami menghendaki niscaya Kami akan berikan kepada tiap-tiap jiwa petunjuk baginya, akan tetapi telah tetaplah perkataan (ketetapan) dari-Ku, sesungguhnya akan Aku penuhi jahanam itu dengan jinn dan manusia sekalilan (QS. AlSajadah, $32: 13)^{46}$

Ayat-ayat di atas dipahami oleh aliran Asy'ariyah bahwa kekuasaan dan kehendak Tuhan itu mutlak (absolut) dan mestilah berlaku (terlaksana). Tidak ada yang membatasinya walaupun diri Tuhan sendiri. Bila tidak mutlak tentu Tuhan lupa, atau lalai atau lemah, padahal yang demikian itu tidaklah pantas (mustahil) bagi Tuhan. Oleh sebab itu kekuasaan dan kehendak Tuhan adalah mutlak dan pasti terjadi. ${ }^{47}$ Seperti Asy'ariyah, Maturidiyah Bukhara juga berpendapat bahwa kekuasan dan kehendak Tuhan mutlak, Tuhan berbuat sekehendak-Nya dan tidak ada satupun yang dapat melarang dan memerintah-Nya, walaupun zat Tuhan sendiri. ${ }^{48}$ Ayat-ayat khusus yang dijadikan dalil oleh Maturidiyah Bukhara tidak ada, kecuali ayat-ayat juga dipergunakan aliran Asy'ariyah.

Dalam Tafsir Depag ayat 112 surat al-An'am dikatakan. "Sekiranya Allah menghendaki supaya syaitan-syaitan itu tidak dapat menipu manusia, tentulah mereka tidak akan dapat berbuat apa-apa. Tetapi Allah memberikan kebebasan kepada manusia untuk memilih apa yang akan mereka kerjakan dan tempuh menurut petunjuk akalnya, jalan yang benar atau sesat. Dan berdasarkan pilihan itulah manusia akan mempertanggungjawabkan segala tingkah lakunya nanti di akhirat". 49

Dalam Tafsir Depag tidak ditemukan secara eksplisit dan tegas mengenai kekuasaan dan kehendak mutlak Tuhan. Tetapi bila dicermati satu per satu penafsiran terhadap ayat-ayat di atas nampaknya tafsir ini memberikan batasan terhadap kekuasaan dan kehendak mutlak Tuhan. Batasan itu terletak pada :

1. Sunnatullah (hukum atau ketentuan Allah) yang tidak berubah-ubah dan pasti terjadi.

2. Adanya kebebasan yang diberikan kepada manusia untuk memilih jalan mana yang akan ditempuhnya (jalan lurus 
atau sesat) yang berdasarkan pilihannya itu Tuhan memberi pahala atau siksa nanti di akhirat.

3. Keadaan Allah dalam melaksanakan kehendak-Nya sesuai dengan sunnah-Nya yang sudah ditetapkan berdasarkan hikmah dan pengetahuan-Nya yang Maha Tinggi.

4. Kepastian Allah menempati janji dan ancaman-Nya nanti bagi manusia.

Jika penafsiran ayat-ayat tentang kekuasaan dan kehendak mutlak Tuhan dalam Tafsir Depag nampaknya corak kalam rasional (Maturidiyah Samarkand), dimana kekuasaan dan kehendak mutlak Tuhan terbatas oleh sunnatullah yang tidak berubah-ubah dan berdasarkan hikmah dan pengetahuan-Nya yang Maha Tinggi, kebebasan yang diberikan kepada manusia, serta janji dan ancaman yang pasti ditepati Tuhan nanti di akhirat. Adanya kesamaan pandangan tafsir ini dengan paham Maturidiyah dapat dipahami karena paham moderat ini lebih dapat diterima oleh kaum intelektual dan perkembangan ilmu pengetahuan yang relative antroposentris dan rasional. Selain itu boleh jadi pengaruh dari tafsir rujukan yang dijadikan sumber dalam penulisan kitab tafsir ini yaitu tafsir al-Maraghi. Pandangan tafsir al-Maraghi terhadap ayat-ayat mengenai kekuasaan dan kehendak mutlak Tuhan, berpendapat bahwa kekuasaan dan kehendak mutlak Tuhan terbatas oleh ikhtiar manusia, kebebasan manusia dalam memilih, janji dan ancaman Allah yang pasti terlaksana serta sunnatullah yang tetap dan tidak berubah, karena itu do'a tidak dapat merubah sunnatullah. ${ }^{50}$

\section{F. Keadilan Tuhan}

Semua aliran dalam teologi Islam memiliki pandangan yang sama bahwa Tuhan tidak akan menyalahi janji-janji-Nya dan menganiaya hamba-Nya. ${ }^{51}$ Tetapi berbeda paradigma dan penekannya dalam kaitan dengan keadilan Tuhan.

Bagi aliran Mu'tazilah keadilan Tuhan dipahami bahwa Tuhan tidak berbuat dan tidak memilih yang buruk dan tidak pula melalaikan kewajiban-kewajiban-Nya kepada manusia dan makhlu-Nya, dan semua perbuatan-Nya adalah baik. ${ }^{52}$ Karena itu Tuhan tidak boleh berbuat zalim. Tidak dapat membebani 
manusia di luar kemampuannya dan wajib menempati janji-Nya nanti di akhirat. Ayat-ayat al-Qur'an yang dijadikan dalil adalah : surat al-Anbiya' (21): 47, surat Yasin (36): 54, surat Fushshilat (41): 46, surat al-Anisa' (4): 40 dan surat al-Kahfi (18): 49, sebaai contoh:

Sesungguhnya Allah tidak Menganiaya seseorang walaupun sebesar zarrah, dan jika ada kebajikan sebesar zarrah, niscaya Allah akan melipat gandakannya dan memberikan dari sisi-Nya pahala yang besar (QS Al-Nisa` (4) : 40)

Sementara Maturidiyah Samarkand kecuali sama pendapat mereka tentang konsep adil bagi Tuhan, menambahkan Tuhan tidak membalasi kejahatan manusia kecuali dengan balasan yang setimpal dan Tuhan tidak akan menganiaya hamaba-hamba-Nya dan juga tidak akan mengingkari janji-janji-Nya yang telah disampaikan kepada hamba-Nya.$^{53}$ Ayat-ayat al-Qur'an yang dijadikan dalil sebagai berikut :

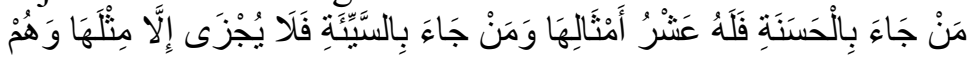

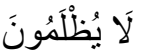

Barangsiapa membawa amal yang baik maka baginya (pahala) sepuluh kali lipat amalnya; dan barangsiapa yang membawa perbuatan yang jahat maka dia tidak diberi pembalasan melainkan seimbang dengan kejahatannya, sedang mereka sedikitpun tidak dianiaya (dirugikan).(QS. Al-An'am, 6 : $160)^{54}$

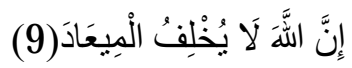

Sesungguhnya Allah tidak menyalahi janji-Nya (QS. Ali Imran, $3: 9)^{55}$

Bagi kalangan tradisional, baik Asy'ariyah dan Matudiriyah Bukhara dalam memahami keadilan bahwa Tuhan sebagai pemilik mutlak mempunyai kekuasaan dan kehendak mutlak terhadap makhluk-Nya (ciptaan-Nya). Dengan kata lain Tuhan adil bila Tuhan dapat berbuat sekehedak-Nya dalam kerajaanNya. Dalam hal ini tidak ditemukan ayat-ayat al-Qur'an secara khusus yang dijadikan dalil naqli oleh kalangan tradisional kecuali ayat-ayat al-Qur'an tentang masalah kekuasaan dan kehendak mutlak Tuhan.

Tafsir Depag dalam menafsirkan Surat al-Anbiya' ayat 47 sebagai berikut : "Bahwa Allah dalam menilai atau melakukan 
hisab atas perbuatan-perbuatan hamba-Nya di akhirat kelak, akan menegakkan neraca keadilan yang benar-benar adil, sehingga tidak ada seorangpun akan dirugikan dalam perhitungan itu. Tidak ada sedikitpun kebaikan akan dikurangi, dan tidak ada seorangpun yang melakukan kejahatan akan dilebihkan azabnya yang menyebabkan penerimanya dizalimi, walaupun Allah kuasa berbuat itu. Karena itu betapapun kecilnya amal perbuatan manusia akan diterima balasannya.

Ayat 54 surat Yasin ditafsirkan bahwa pada hari kiamat nanti semua manusia akan menerima balasan atas semua perbuatan yang telah dilakukan selama hidup di dunia. Kebaikan akan dibalas dengan pahala yang berlipat ganda dan kejahatan akan dibalas dengan hukuman yang seimbang, seorang tidak akan memikul dosa orang lain. Inilah keadilan Tuhan yang dijanjikan kepada manusia.

Dari kutipan-kutipan penafsiran diatas dapat ditarik kesimpulan bahwa konsep keadilan Tuhan yang terdapat dalam kitab TafsirDepag adalah :

1. Bahwa Allah akan memberikan hak-hak hamba-hamba-Nya sesuai dengan apa yang diperbuat, betapapun kecil perbuatannya dan tidak akan dianiaya (dikurangi) sedikitpun, dan tidak akan dialihkan pahala atau kejahatan seseorang kepada orang lain, kecuali kepada pelakunya.

2. Allah memberikan pahala berlipat ganda kepada orang yang melakukan kebaikan dan hukuman yang setimpal kepada pelaku kejahatan atau lebih ringan dari itu, jika Allah menghendaki.

3. Dan janji Allah kepada manusia itu pasti akan ditepati nanti di akhirat, dan mustahil bagi Allah untuk melanggar janjiNya.

Jadi konsep keadilan Tuhan yang terdapat dalam kitab Tafsir Depag lebih cenderung kepada pandangan Maturidiyah Samarkand, dimana keadilan Tuhan sebagai lawan sifat zalim yang mustahil bagi Tuhan untuk berlaku zalim, keadaan Tuhan memberi hukuman yang setimpal dan kepastian Allah menepati janji-Nya nanti. Dengan kata lain konsep keadilan Tuhan dalam tafsir Depag lebih bercorak moderat antara rasional dengan tradisional. 


\section{G. Perbuatan-perbuatan Tuhan}

Semua aliran dalam teologi Islam sama pandangannya bahwa Tuhan melakukan perbuatan-Nya sebagai akibat dari Dia mempunyai Qudrat dan iradat, tetapi mereka berbeda pendapat apakah Tuhan berbuat yang baik-baik saja atau juga yang buruk (tidak baik). Bagi kalangan teologi tradisional, baik Asy'ariyah dan Maturidiyah Bukhara memahami keadilan bahwa Tuhan sebagai Pencipta dan Pemilik mutlak mempunyai kehendak dan kekuasaan mutlak terhadap Makhluk-Nya dan milik-Nya (ciptaan-Nya). Dengan kata lain Tuhan adil bila Tuhan dapat berbuat sekehendak-Nya dalam kerajaan-Nya. ${ }^{57}$ Dalam hal ini tidak ditemukan ayat-ayat al Qur'an secara khusus yang dijadikan dalil naqli oleh kalangan teologi tradisional kecuali ayat-ayat al Qur'an tentang masalah kekuasaan dan kehendak Mutlak Tuhan

Bagi kaum Mu'tazilah Tuhan terbatas perbuatan-Nya pada perbuatan yang baik-baik saja, sebab sejalan dengan nama Tuhan Yang Maha Baik. Ini berarti Tuhan tidak mampu melakukan yang buruk dan lagi pula bertentangan dengan keadilan, orang yang zhalimlah yang dapat melakukan yang buruk. Ayat-ayat al Qur'an yang dijadikan dalil adalah :

Allah tidak menjadikan langit dan bumi dan apa yang ada diantara keduanya melainkan dengan tujuan yang benar (QS. Al-Rum, $30: 8)^{58}$

Ayat-ayat di atas menurut Abd al-Jabbar menunjukan bukti Tuhan tidak ditanya tentang apa yang Dia perbuat, manusialah yang ditanya. Sebab zat yang Maha Baik secara nyata akan melakukan yang baik (benar). Maka Dia tidak perlu ditanya tentang perbuatan-Nya itu, sebab Allah telah melakukannya dengan baik (benar) ${ }^{59}$ Dengan demikian kaum Mu'tazilah berpendapat bahwa Tuhan wajib melakukan perbuatan baik dan terbaik (al-salah wa al-aslah). Diantara perbuatan baik yang dilakukan Tuhan adalah mengutus rasul kepada umat manusia. ${ }^{60}$

Dalam masalah ini Maturidiyah Samarkand sama pendapat mereka dengan Mu'tazilah dimana perbuatan Tuhan hanyalah menyangkut yang baik saja. Karena itu pengiriman Rasul kepada umat manusia adalah perbuatan baik yang wajib 
dilakukan oleh Tuhan. Ayat-ayat yang dijadikan dalil dalam mendukung pendapat ini sejauh yang penulis ketahui belum ada.

Sementara kalangan teologi tradisional yang berpegang pada kekuasaan dan kehendak mutlak Tuhan, berpendapat bahwa Tuhan tidak punya kewajiban-kewajiban dan karenanya Tuhan dapat berbuat apa saja yang Dia kehendaki (perbuatan baik dan buruk). Tetapi dalam kaitan menepati janji-janji-Nya nanti di akhirat Maturidiyah Bukhara berpendapat bahwa Tuhan mesti melaksanakannya, pengutusan Rasul adalah mungkin bagi Tuhan. Ayat-ayat al Qur'an yang dijadikan sandaran tidak ditemukan secara khusus kecuali ayat-ayat tentang kekuasaan dan kehendak Mutlak Tuhan.

Tafsir Depag dalam menafsirkan ayat-ayat yang berkenaan dengan Tuhan berbuat baik dan terbaik (al-sâlah wa al-aslah), tidak membebani manusia dengan kewajiban di luar kemampuannya (taklif mâ lâ yutaq), dan pengiriman Rasul dan kewajiban Tuhan menepati janji dan melaksanakan ancamanNya (al wa'd wa al-wa'id) nanti di akhirat. Pandangan Tafsir Depag agak cenderung kepada pemikiran kalam Maturidiyah Samarkand, dimana Tuhan dalam melaksanakan perbuatan-Nya dengan penuh hikmah dan keadilan serta sesuai dengan rencana dan kehendak-Nya. Kesimpulan ini dapat diperkuat ketika menafsirkan surat al-'Ankabut ayat 44 dan Shad ayat 27 dan alDukhan ayat 38-39.

\section{H. Sifat-Sifat Tuhan \\ 1. Antropomorphisme.}

Pembicaraan mengenai hal ini berkaitan dengan sifat-sifat yang menggambarkan bahwa Tuhan memiliki sifat-sifat jasman atau fisik. Bagi kaum Mu'tazilah ayat-ayat al Qur'an yang menggambarkan Tuhan memiliki sifat-sifat jasmani harus diberi ta'wil dengan pengertian yang layak bagi kebesaran dan keagungan Tuhan. Ayat-ayat al Qur'an yang dijadikan dalil surat Thaha (20) 5 dan 39, surat al-Qashash (28) 88, surat Shad (38): 75, surat al-Zumar (39): 67 dan surat al-Fajr (89): 22, sebagai contoh:

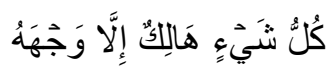


Tiap-tiap sesuatu pasti binasa kecuali Allah (QS. AlQashash, 28:88) ${ }^{61}$

Ayat-ayat di atas yang menggambarkan seolah-olah Tuhan mempunyai sifat jasmani (antropomorphisme), tetapi tidak dapat dikatakan demikian kata Abd al-Jabbar, sebab kalau Tuhan mempunyai sifat-sifat jasmani tentu Tuhan memiliki panjang, lebar, tinggi dan dalam. Padahal yang demikian mustahil bagi Tuhan, karena itu ayat di atas harus dipahami secara metafor (majazi) atau diberi takwil ${ }^{62}$. Kata istawa dalam ayat 5 surat Thaha di atas dipahami al-istila`wa al-qalabah (menguasai dan mengalahkan), kata `aini dalam ayat 39 dipahami dengan 'ilmi. Kata wajhah dalam ayat 88 surat al-Qashash dengan zatuhu ay nasuhu (zat-Nya yang diyakini diri-Nya). Kata yad dalam ayat 75 surat Shad dengan al-Quwwah (kekuatan), kata yamin ayat 67 al-Zumar dengan al-Quwwah dan kata ja'a rabbuka ayat 22 al-Fajr dengan ja'a amru rabbuka (telah datang urusan Tuhanmu) ${ }^{63}$.

Dalam kaitan ini Maturidiyah Samarkand sependapat dengan Mu'tazilah bahwa Tuhan tidak mempunyai sifat-sifat jasmani. Karena ini ayat-ayat yang menggambarkan Tuhan mempunyai tangan, wajah, mata, kaki adalah kekuasaan Tuhan. ${ }^{64}$

Bagi kaum Asy'ariyah, seperti yang dikutip dari pendapat Asy'ari menolak sifat-sifat jasmani yang ada pada Tuhan bila sifat jasmani dipandang sama dengan sifat jasmani manusia juga. Tetapi ayat-ayat al Qur'an yang menggambarkan Tuhan memiliki sifat jasmani tidak boleh ditakwil dan harus diterima sebagaimana makna harfinya. Oleh sebab itu Tuhan mempunyai mata, wajah, tangan dan sebagainya. Namun semua sifat-sifat itu dikatakan la yukayyaf wa la yuhad (tanpa diketahui bagaimana cara dan batasannya). ${ }^{65}$ Jadi mereka tetap mengatakan bahwa Tuhan tidak mempunyai sifat jasmani seperti mahluk, seperti firman Tuhan :

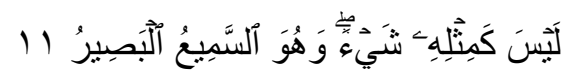

Tidak ada sesuatupun yang serupa dengan Dia, dan Dialah Yang Maha Mendengar lagi Maha Melihat (QS. Al-Syura, 42 : 11) 
Maturidiyah Samarkand Bukhara pendapat mereka Tuhan tidak mempunyai sifat-sifat jasmani, ayat-ayat al Qur'an yang menggambarkan Tuhan memiliki sifar jasmani harus ditakwil. Kata istawa menurut al-Bazdawi harus dipahami dengan arti alistila' 'ala al-syai'i wa al-qahr 'alaihi (menguasai sesuatu dan memaksanya). ${ }^{66}$ Karena itu ayat-ayat al Qur'an yang menggambarkan Tuhan punya dua mata, dua tangan dan lain sebagainya, bukan berarti Tuhan punya anggota badan.

\section{Ru'yatullah.}

Masalah ini berkaitan dengan melihat Tuhan di akhirat nanti. Apakah Tuhan dapat dilihat dengan mata kepala atau dengan rohani. Dalam pandangan Mu'tazilah Tuhan tidak dapat dilihat dengan mata kepala di akhirat nanti, sebab Tuhan tidak tersusun dari materi dan bentuk atau dengan kata lain Tuhan Immateri. Kalau Tuhan dapat dilihat dengan mata kepala tentu Tuhan mengambil tempat, ruang dan tentu Tuhan dapat dilihat sekarang dan nanti. Ayat-ayat al Qur'an yang dijadikan dalil oleh Mu'tazilah adalah : surat al-An`am (6): 103, surat alQiyama (72): 22-23, surat al-`Araf (7): 143, surat al-Kahfi (18): 107, surat al-Syura (42): 51, sebaai contoh: ${ }^{67}$

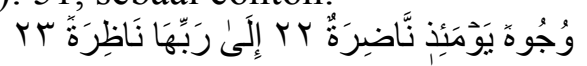

Wajah-wajah (orang-orang mukmin) pada hari itu berseriseri. Kepada Tuhannyalah mereka melihat (QS Al-Qiyamah, 75 :22-23) ${ }^{68}$

Ayat-ayat di atas memberi penjelasan bahwa Tuhan tidak dapat dilihat dengan mata kepala kapan dan dimana saja. Kata nafy pada ayat 103 al-An'am berlaku untuk di dunia dan di akhirat kelak. Kata Nazhirah dalam ayat 22-23 surat alQiyamah dipahami menunggu pahala. Kata lan tarani dalam ayat 143 al-'A'raf berarti Aku sekali-kali tidak dapat dilihat, sebagai jawaban Tuhan atas permintaan Musa yang ingin melihat Tuhan. ${ }^{69}$

Sebaliknya kalangan Asy'ariyah, seperti pendapat Asy'ari bahwa Tuhan dapat dilihat dengan mata kepala di akhirat nanti, sebab sesuatu yang dapat dilihat adalah sesuatu yang mempunyai wujud, karena itu berwujud maka Tuhan dapat dilihat. Tuhan mampu melihat diri-Nya dan manusia, karena itu 
juga mampu menciptakan manusia yang punya kemampuan melihat diri-Nya. ${ }^{70}$ Ayat-ayat al Qur'an yang dibawa sebagai dalil adalah surat Yunus (10) ayat 26, al-Qiyamah (75) ayat 2223, al-An'am (6) ayat 103 dan al-A'raf (7)ayat 143, sebaai contoh:

Bagi orang-orang yang berbuat baik ada pahala yang baik (sorga) dan tamabahannya (QS. Yunus, 10:26)

Kata ziyadah dalam ayat 26 surat Yunus di atas dipahami bahwa selain pahala sorga, balasan bagi orang mukmin adalah melihat Tuhan dengan mata kepala, dan kata nazirah ( نَاظِرَّة dalam ayat 22-23 al-Qiyamah bermakna I'tibar (memperhatikan) atau intizar (menunggu) bila kata itu dituturkan dengan wajah, maka mengandung arti melihat dengan kedua mata yang terdapat pada wajah. ${ }^{71}$ Sedangkan kata nafy dalam ayat 103 al-An'am ditafsirkan bahwa Tuhan tidak dapat dilihat di dunia baik oleh orang mukmin atau kafir, tetapi ia dapat dilihat di akhirat nanti hanya oleh orang mukmin. ${ }^{72}$ Permintaan Musa untuk melihat Tuhan dalam ayat 143 al-A'raf bukanlah sesuatu yang mustahil, tetapi itu adalah hal yang mungkin. Alasan kemampuan melihat gunung yang tidak hancur, tidak harus yang membuat gunung (Tuhan) tidak dapat dilihat. $^{73}$

Sejalan dengan Asy'ariyah adalah Maturidiyah Samarkand, sebagaimana yang dijelaskan Maturidi melihat Tuhan di akhirat nanti dengan mata kepala bukanlah sesuatu hal yang mustahil, melainkan mesti dan benar. Namun bagaimana cara melihatnya tidak dapat dijelaskan. Ayat 103 al-An'am ditafsirkan Maturidi bahwa Tuhan tidak dapat dilihat, maka penafsiran al-Idrak (penangkapan dengan cara-cara yang jelas) tidak ada artinya. Sebab selain Tuhan ditangkap dengan pandangan, maka menempatkan nafy al-Idrak untuk menangkap selain Tuhan tidak ada maknanya. Karena itu Tuhan dapat dilihat dengan mata. $^{74}$

Ayat 143 surat al-A'raf ditafsirkan Maturidi bahwa manusia juga dapat melihat Tuhan sebab Musa minta Tuhan untuk dapat dilihat, sementara Tuhan sendiri tidak dapat dilihat, berarti Musa adalah seorang yang bodoh. Padahal Musa adalah seorang pembawa risalah dan penerima wahyu. Kata wajah-wajah 
dalam ayat 22-23 al-Qiyamah juga ditafsirkan dengan melihat Tuhan bukan menunggu. ${ }^{75}$

Maturidiyah Bukhara sependapat dengan Asy'ariyah dan Maturidiyah Samarkand, bahwa Tuhan dapat dilihat nanti di akhirat dengan mata kepala. Sebab Tuhan akan memperlilhatkan diri-Nya kepada manusia (beriman) menurut apa yang Dia kehendaki dan maui di akhirat. ${ }^{76}$

\section{Khalq al-Qur'an.}

Timbulnya persoalan ini adalah untuk menjawab permasalahan apakah kalamullah atau al-Qur'an itu qadim atau diciptakan. Pendapat yang mengatakan bahwa al-Qur'an itu qadim, karena ia adalah kalam Allah yang merupakan sifat Tuhan, dan sifat Tuhan itu mesti qadim (tidak diciptakan). Bagi yang mengatakan al-Qur'an itu diciptakan beragumen karena alQur'an itu tersusun dari kata-kata dan diturunkan secara berangsur-angsur, karena itu ia tidak mesti qadim. Mu'tazilah berpendapat dengan pendapat kedua, al-Qur'an diciptakan. Ayat-ayat al-Qur'an yang dijadikan dalil adalah :

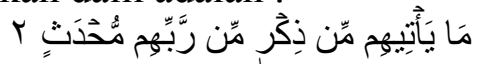

Telah datang kepada mereka suatu ayat al-Qur'anpun yang baru (QS. al-Anbiya, 12 :2). ${ }^{77}$

Berturut-turut ayat-ayat di atas ditafsirkan oleh Abd AlJabbar bahwa al-Qur'an (al-zikr) disifati dengan baru. Sebab ia diturunkan dan dipelihara oleh Tuhan. Sesuatu yang qadim tidak perlu dipelihara, kecuali yang baru. Al-Qur'an itu terdiri dari huruf-huruf dan terkumpul (tersusun) menjadi satu, turun secara berulang-ulang dan tertulis. Sifat-sifat itu semua menunjukan sifat yang baru bukan qadim, karena itu al-Qur'an adalah baru.

Asy'ariyah, Maturidiyah Samarkand dan Maturidiyah Bukhara menganut pendapat pertama yaitu al-Qur'an itu adalah kalamullah yang qadim, sebab al-Qur'an itu bukan yang tersusun dari huruf-huruf dan bersuara, tetapi dibalik yang tersusun dan bersuara itu. ${ }^{78}$ Ayat-ayat al-Qur'an yang dijadikan dalil adalah : surat al-Rum (30): 25, surat Yasin (36) : 82, surat Al-Kahfi (18) : 109 dan surat al-Mu 'min (40): 16, sebagai contoh:

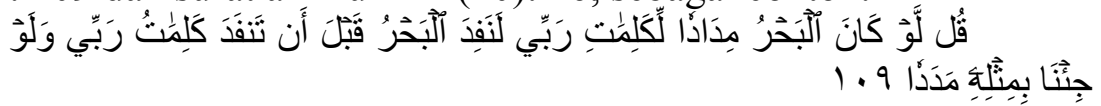


Katakanlah: "Kalau sekiranya lautan menjadi tinta untuk menuliskan kalimat-kalimat Tuhan, sungguh habislah lautan itu sebelum habis ditulis kalimat-kalimat Tuhanku (QS. Al-Kahfi, $18: 109)^{79}$

Dalam hal sifat-sifat Allah mengenai sifat tasybih (antropomorphisme), khalq al-Qur'an (sifat kalam) dan melihat Tuhan di akhirat (eksotologi). Corak paham teologi yang ditemukan dalam Tafsir Depag dapat disimpulkan dari penefsiran ayat yang dijadikan dalil oleh teologi rasional dan tradisonal.

Sebagai contoh Al-Zumar ayat 67 dipahami bahwa bumi dalam genggaman-Nya dan langit digulung dengan tangan kanan-Nya adalah alam itu ada dalam kekuasaan-Nya. Hakekat yang sebenarnya dari tanggan Allah tidak dapat diketahui, karena termasuk hal yang ghaib diserahkan kepada Allah, dan Allah tidak ada yang menyerupai-Nya ${ }^{80}$

Tafsir Depag mengakui adanya sifat-sifat Tuhan, dan sifatsifat yang menggambarkan Tuhan berjisim (antropomorphisme) diyakini ada, tetapi hakekatnya tidak sama dengan yang ada pada manusia (makhluk). Namun demikian seperlunya dilakukan juga pentakwilan, seperti kata 'aiyuni dengan pemeliharaan dan pengawasan, wajhah dengan zat Tuhan, yad dengan kekuasaan (kekuatan) dan karunia.

Dengan demikian kecenderungan penafsiran ayat-ayat antropomorphisme dalam Tafsir Depag adalah moderat antara Asy'ariyah dengan Maturidiyah Samarkand. Sebab disatu sisi menerima antropomorphisme yang hakekatnya diserahkan kepada Tuhan, tetapi di sisi lain diupayakan pentakwilan seperti yang dilakukan al-Maturidi atau Mu'tazilah

Dalam hal kebaharuan al-Qur'an sebagai kalamullah tidak ditemukan penjelasan secara tegas, tetapi dengan memperhatikan definisi yang diberikan terhadap bahwa alQur'an adalah kalamullah (firman Allah) yang diturunkan kepada Nabi Muhammad SAW dalam bahasa Arab melalui makailat Jibril yang dimulai dari surat al-Fatihan dan ditutup dengan surat al-Nas diterima secara mutawatir dan terhimpun dalam mushaf. ${ }^{81}$ Dan al-Qur'an itu adalah salah satu dari 
aktualisasi sifat kalam Allah dan sifat Allah itu adalah qadîm, maka dapat diduga al-Qur'an itu adalah qadîm.

Ayat 26 surat Yunus ditafsirkan bahwa balasan pahala bagi orang yang melakukan amal kebaikan adalah sorga dan ditambah dengan kenikmatan melihat (mengetahui) dengan sebenarnya. ${ }^{82}$ Dan diterangkan lagi dalam ayat 35 surat Qaf, bahwa balasan bagi mereka disediakan dalam sorga apa saja yang mereka inginkan, kenikmatan yang belum pernah mereka lihat dengan mata, belum pernah mereka dengar dengan telinga dan belum pernah terbayangkan dalam hati, dan ditambah lagi dengan melihat Tuhan sebagai puncak dari segala kenikmatan. ${ }^{8}$

Dari kutipan penafsiran ayat-ayat di atas dapat ditarik kesimpulan bahwa dalam Tafsir Depag Tuhan dapat dilihat nanti di akhirat dengan mata kepala sebagai kenikmatan yang tertinggi bagi mereka yang mukmin. Dan tidak akan terjadi bagi mereka yang kafir, sebab mereka telah tertutup dari nikmat melihat Tuhan. Kalau diamati masalah ru'yatullah dalam Tafsir Depag dekat kepada paham Asy'ariyah (ahl al-sunnah wa aljama'ah).

\section{Corak Teologi Islam Dalam Tafsir Karya Departemen Agama}

Penafsiran terhadap ayat-ayat kalam dalam Tafsir Depag memiliki kecenderungan agak dekat kepada corak pemikiran kalam rasional-Maturidiyah Samarkand. Sebaliknya sedikit sekali persamaannya dengan kalam tradisional (Asy'ariyah dan Maturidiyah Bukhara). Dalam membicarakan kemampuan akal dan fungsi wahyu, ada persamaannya dengan paham kalam Maturidiyah Bukhara, tetapi pendapat dalam Tafsir Depag lebih maju, dimana akal punya potensi mengetahui Tuhan, mengetahui Tuhan itu Esa, mengetahui baik dan buruk, mengetahui dasar adanya kebaikan dan keburukan serta mengetahui adanya kehidupan akhirat.

Semua kewajiban diketahui melalui agama (wahyu) yang dibawa oleh para rasul, dan pengutusan rasul adalah sunatullah bukan jaiz seperti pendapat kalangan Maturidiyah Bukhara. Dalam hal Khalq al-Qur'an dan melihat Tuhan nanti di akhirat penafisran Tafsir Depag cenderung kepada pemikiran kalam 
tradisional-Asy`ariyah. Yaitu al-Qur'an itu Qadim dan Tuhan dapat dilihat nanti dengan mata kepala oleh yang beriman sebagai balasan yang tertinggi atas kebaikan yang telah dilakukannya selama di dunia.

Persamaan penafsiran ayat-ayat kalam Tafsir Depag dengan pemikiran kalam rasional-Maturidiyah Samarkand :

1. Dalam hal Qadariyah dan Jabariyah (free will and predestination) dikatakan bahwa manusia mempunyai ikhtiar (daya untuk memilih) dan kebebasan untuk melakukan atau tidak melakukan suatu perbuatan, dan atas dasar pilihan itulah Allah memberi upah dan balasan nanti di akhirat yang tidak akan dikurangi sedikitpun. Nasib yang terjadi pada manusia, adalah sunatullah atau adanya rangkaian causalitas, bukan ketetapan Tuhan.

2. Iman terletak pada keyakinan yang mendalam terhadap Tuhan dengan segala aspek-aspek yang terkait dengannya, yang direalisasikan lewat amal (perbuatan), amal dapat membuat iman bertambah dan berkurang, rusak dan sempurna. Dengan kata lain iman adalah amal yang lahir dari keyakinan yang medalam (ma'rifah). Karena itu iman tidak cukup iqrar bi al-lisan dan tadiq bi al-qalb, tapi harus meningkat ke ma'rifah dan amal.

3. Kekuasaan dan kehendak mutlak Tuhan terbatas oleh sunatullah yang tak berubah-ubah, keadaan Allah menetapkan sunatullah-Nya sesuai dengan hikmah dan pengetahuan-Nya yang Maha Tinggi, kebebasan yang diberikan-Nya kepada manusia, dan prinsipnya Allah nanti menepati janji dan melaksanakan ancaman-Nya.

4. Keadilan Tuhan dilihat sebagai lawan dari sifat zalim yang mustahil bagi Tuhan, Tuhan adil jika membalasi hukuman yang setimpal dan menempati janjinya serta melipatgandakan pahala sesuai dengan kehendak-Nya.

5. Tuhan dalam melaksanakan perbuatan-Nya sesuai dengan hikmah dan keadlian-Nya, karena itu tidaklah sesuai dengan sunnah-Nya kalau Tuhan membebani manusia diluar kemampuannya (taklif ma la yutaq), kalau tidak mengutus rasul dan tidak melaksanakan al-wa'd wa al-wa'id. 
6. Dalam hal antropomorphisme (sifat kejisiman) yang menggambarkan Tuhan mempunyai sifat jasmani diyakini ada, tapi hakekatnya tidak sama dengan yang ada pada makhluk, karena itu seperlunya dilakukan pentakwilan terhadap ayat-ayat antropomorphisme. Seperti kata wajh dengan zat Tuhan, yad dengan kekuasan, dan karunia Tuhan.

Kecenderungan penafsiran ayat-ayat kalam dalam Tafsir Depag kepada pemikiran kalam rasional mungkin disebabkan oleh beberapa hal. Pertama karena kitab tafsir yang menjadi rujukan kebanyakan dari kitab tafsir yang ditulis pada periode modern, dan bernuansa rasional seperti kitab tafsir: Al-Alusi, alMaraghi, Al-Manar, Al-Qasimi, Sayid Qutb, dan al-Wadlih. Kedua karena sebagian besar penyusun tafsir ini adalah ulama keluaran Mesir dan murid langsung dari Al-Maraghi, dan kecenderungan pemikiran kalam tafsir Al-Maraghi bercorak rasional. Ketiga karena tafsir ini merupakan suatu kitab tafsir standar yang diharapkan dibaca oleh banyak umat Islam (kalangan umum dan intelektual) di Indonesia, yang sedang dalam proses pembangunan dan memerlukan suatu semangat kerja atau ikhtiar untuk cepat bangkit dari kemunduran. Keempat secara tidak langsung corak rasional tafsir ini sebagai akibat dari perkembangan modern di dunia Islam, yang salah satunya dicirikan dengan sikap rasional dan apresiatif terhadap perkembangan ilmu pengetahuan dan teknologi modern. Dan pada tahun tujuh puluhan di Indonesia sedang terjadi wacana keIslaman dan kemodernan yang dikembangakan di Perguruan Tinggi Islam seperti Istitut Agama Islam Negeri ( IAIN).

3 Perubahan SK ini terjadi waktu Menteri Agama dipegang oleh Alamsyah Ratuperwira negara. Waktu itu pentafsiran Al-Qur'an sudah selesai 24 Juz, tinggal lagi yang belum selesai 6 Juz, oleh menteri kegiatan pentafsiran Al-Qur'an ini dilaporkan sudah selesai sebanyak 30 Juz karena terkait dengan pendanaan, oleh Ketua tim waktu itu Prof. Bustami A. Gani, tidak mau melaporkan hasil yang belum selesai, karena itu menteri mengambil keputusan dengan memperbarui personalia tim ini, dan tim yang terakhir inilah yang menuntaskan penafsiran Al-Qur'an yang ada sekarang (Wawancara Ibid). Lihat juga Muqadimah, h. 11. 
${ }^{4}$ Hasan Zaini, Tafsir Tematik Ayat-ayat Kalam Tafsir al-Maraghi, (Jakarta: Pedoman Ilmu Jaya, 1997), h. 18-19.

${ }^{5}$ Departemen Agama RI, Al-Qur'an dan Tafsirnya, jilid I, h. 7.

${ }^{6}$ Departemen Agama RI, Al-Qur'an dan Tafsirnya Jilid I, (Jakarta: CV. Ferlia Citra Utama, 1996), h. VIII (selanjutnya disebut Al-Qur'an dan Tafsirnya)

${ }^{1}$ Departemen Agama, Al-Qur'an dan terjemahnya, h. VII

${ }^{2}$ Departemen Agama, Al-Qur'an dan terjemahnya, h. VII

3 Al-Tafsir al Tahlil adalah suatu metode tafsir yang bermaksud menjelaskan kandungan ayat-ayat al-Qur'an dari seluruh aspeknya dengan mengikuti runtutan (urutan) ayat sebagaimana yang telah tersusun dalam mushaf. Penafsir memulai uraiannya dengan mengemukakan munasabah (korelasi) ayat-ayat serta menjelaskan hubungan ayat-ayat itu satu sama lain, juga dibahas sebab turunnya ayat (sabab al-nuzul) dan (Ithnab). Sedang (musawah) dan ringkasan atau sederhana (ijaz). Metode tafsir Tahlili dibedakan menurut corak atau kecenderungannya kepada : al-Tafsir bi alMatsur, al-tafsir bi al-Ra'yi,al-tafsir al-Shufi, al-tafsir al-fiqhi, al-tafsir afalsafi, al-tafsir al-Ilmi dan al-tafsir al-adai al-Ijtima'I ('Ali Hasan al'ardl, , Al-Tarikh Ilm Tafsir Wal Mufasirun, h. 41-42, lihat juga Abd. Al-Hayy alFarmawi, al-Bidayah Fi Tafsir al-Maudui h.12).

${ }^{4}$ Dalam pemikiran kalam tafsir ini agak dekat ke pemikiran kalam Mu'tazilah dan Maturidiyah Samarkand (kalam rasional), Hasan Zaini, Hasan Zaini, Tafsir Tematik Ayat-ayat Kalam Tafsir al-Maraghi. h. 181

${ }^{5}$ Sayid Qutub adalah seorang tokoh ideologis da Ikhwan al-Muslimin yang dapat digolongkan pda gerakan Neo-Rivivalisme Islam. Dalam tafsir ia menempuh metode,pertama ia memaparkan naungan pada mukadimah setiap surat untuk mengaitkan atau mempertemukan antara bagian-bagian untuk menjelaskan tujuan dan maksudnya. Sesudah itu baru ia menafsirkan ayat dengan mengetengahkan hadist-hadist (atsar) sahih, lalu mengemukakan satu paragraf tentang kajian kebahasan secara singkat. Kemudian ia mencoba mengkaitkan ayat itu dengan membangkitkan kesadaran membetulkan pemahaman serta mengkaitkan Islam dengan persoalan kehidupan umat dewasa ini. Dan dengan tafsir ini ia yakin akan dapat diupayakan generasi yang Qur'ani. Mana Khalil al-Qattan, Mabahis Fi Ulum al-Qur'an. h.514

${ }^{6}$ Ali Hasan Al-‘Ardl, , Al-Tarikh Ilm Tafsir Wal Mufasirun, h. 68-72. Abd Al-Hayy al-Farmawi, al-Bidayah Fi Tafsir al-Maudui. h. 27-29

${ }^{7}$ Tafsir ini termasuk kitab tafsir dengan pembahasan yang panjang lebar yang dianggap sebagai kitab tafsir yang bersih dan memberitahukan bagaimana metode tafsir orang-orang terdahulu, Abdul Jalal HA, op.cit.h. 73

${ }^{8}$ Mana Khalil al-Qattan, Mabahis Fi Ulum al-Qur'an. h. 520

${ }^{9}$ Kitab tafsir ini merupakan kitab tafsir yang membahas secara mendetail dan mencakup riwayah dan dinayah dirayah yang mengutamakan dalil-dalil dari mahzab ahl al-sunnah dan termasuk tafsir dengan fokus 
pembahasan aqidah (tauhid. Muhammad Ali Al-Shabuni, Sofwatut Tafasir h..264)

${ }^{10}$ Ali Hasan al-'Aridl, , Al-Tarikh Ilm Tafsir Wal Mufasirun, h. 60

${ }^{11}$ Kitab tafsir ini memiliki keistimewaan karena perhatiannya yang cukup besar terhadap menafsirkan al-Qur'an dengan al-Qur'an, kemudian dengan hadis-hadis marfu' yang ada relevansi dengan ayat yang ditafsirkan, diikuti dengan atsar para sahabat, pendapat tabi'in dan ulama salaf. Dan selalu ia memperingatkan cerita-cerita Isra'iliyat yang tertolak (munkar) yang benayak terdapat dalam tafsir bi al-Ma'tsur. Ibn Katsir adalah seorang ahli fiqh, ahli hadis dan ahli sejarah, karena itu tafsirnya menjadi tafsir bi alMa'tsur tersebut kedua setelah Al-Thabari. Mana Khalil al-Qattan, Mabahis Fi Ulum al-Qur'an, h. 527-528, Muhammad Ali al-Shubuni, Sofwatut Tafasir h.260-261. M. Yunan Yusuf, Penafsiran Ayat-ayat Kalam Mu'tazilah menurut Asy'ariyah dan Ayat Kalam Asy'ariyah menurut Mu'tazilah, (PP. IAIN Syahid: Jakarta, 1997), h. 3.

${ }^{12}$ Ada yang membedakan dari sudut sistematika ini kepada al-Manhaj al-Basith, al-Manhaj al-Wasith dan al-Manhaj al-Mabsuth, ada lagi memakai istilah al-Mukhtashar (ringkas), al-Wasith (sedang) dan al-Mabsuth (luas). Yang lain membagi Ithnabi, Ijazi dan Musawah. Abdul Djalal HA, Ulumul Qur'an, h. 78-81. 'Ali Hasan al-'Aridl, Al-Tarikh Ilm Tafsir Wal Mufasirun, h. 42.

${ }^{13}$ Harun Nasution, Teologi Islam, (Jakarta: UI Press, 1987), h. 80

${ }^{14}$ Departemen Agama, Al-Qur'an dan terjemahnya h. 781

15 Abu al-Yusr Muhammad bin Muhammad bin Abd al-Karim alBazdawi, kitab Ushul alDin. (cd) Hans Peter Linss, (Kairo: Isa al-Babi al Halabi. 1963), h. 208-209 (selanjutnya disebut Kitab Ushul) lihat juga M. Yunan Yusuf, Penafsiran Ayat-ayat Kalam Mu'tazilah menurut Asy'ariyah, h. 85

${ }^{16}{ }^{16}$ Harun Nasution, Teologi Islam, h. 82-94

${ }^{17}$ Departemen Agama, Al-Qur'an dan terjemahnya, h. 426

${ }^{18}$ Departemen Agama, Al-Qur'an dan terjemahnya, h. 29-32

${ }^{19}$ Departemen Agama, Al-Qur'an dan terjemahnya, h. 33-34

${ }^{20}$ Departemen Agama, Al-Qur'an dan terjemahnya, h. 21 dan 36

${ }^{21}$ Departemen Agama, Al-Qur'an dan terjemahnya Juz XXX, h. 714

${ }^{22}$ Departemen Agama, Al-Qur'an dan terjemahnya, Juz VI, h. 347-

${ }^{23}$ Departemen Agama, Al-Qur'an dan terjemahnya, Juz XV, h. 296

${ }^{24}$ Harun Nasution, Teologi Islam, h. 99

${ }^{25}$ Harun Nasution, Teologi Islam, h. 100

${ }^{26}$ Departemen Agama, Al-Qur'an dan terjemahnya juz I, h. 33

${ }^{27}$ Departemen Agama, Al-Qur'an dan terjemahnya juz I, h. 36

${ }^{28}$ Departemen Agama, Al-Qur'an dan terjemahnya juz I, h. 37

${ }^{29}$ Departemen Agama, Al-Qur'an dan terjemahnya juz I, h. 37

${ }^{30}$ Departemen Agama, Al-Qur'an dan terjemahnya Juz VI, h. 349 
${ }^{31}$ Qadi Abd al-Jabbar, Syarh al-Ushul al-Khamsah, (ed), Abd alKarim Usman, (Kairo: Maktabah Wanbah, 1965), h. 361-362 (selanjutnya disebut Syarh) lihat M. Yunan Yusuf. Penafsiran Ayat-ayat Kalam Mu'tazilah menurut Asy'ariyah h. 90

${ }^{32}$ Harun Nasution, Teologi Islam Ibid, h. 132

${ }^{33}$ Harun Nasution, Teologi Islam h. 198 dan 104

${ }^{34}$ Harun Nasution, Teologi Islam, h. 107

${ }^{35}$ Harun Nasution, Teologi Islam, h. 107

${ }^{36}$ Harun Nasution, Teologi Islam,h.107

${ }^{37}$ Qadi Abd al-Jabbar, Syarh al-Ushul al-Khamsah,, h.107, lihat juga Teologi Islam, h.114-115

${ }^{38}$ Qadi Abd al-Jabbar, Syarh al-Ushul al-Khamsah, h.102-104, lihat juga M.Yunan Yusuf, Penafsiran Ayat-ayat Kalam Mu'tazilah menurut Asy'ariyah, h.97

${ }^{39}$ Departemen Agama, Al-Qur'an dan terjemahnya, Juz V. h. 223

${ }^{40}$ Departemen Agama, Al-Qur'an dan terjemahnya, Juz XV, h. 715

${ }^{41}$ Departemen Agama, Al-Qur'an dan terjemahnya, Juz XV h. 679

${ }^{42}$ Harun Nasution, Teologi Islam, h. 120

${ }^{43}$ Harun Nasution, Teologi Islam, h. 122

${ }^{44}$ Departemen Agama, Al-Qur'an dan terjemahnya juz XV, h. 168

${ }^{45}$ Harun Nasution, Teologi Islam, h. 118-119

${ }^{46}$ Departemen Agama, Al-Qur'an dan terjemahnya juz XV, h. 661

${ }^{47}$ Al-Luma', h. 47

${ }^{48}$ Qadi Abd al-Jabbar, Syarh al-Ushul al-Khamsah,, h. 130

${ }^{49}$ Departemen Agama, Al-Qur'an dan terjemahnya, Juz VIII h. 255

${ }^{50}$ Hasan Zaini, Tafsir Tematik Aayat-ayat Kalam Tafsir al-Maraghi, h. 105-113.

${ }^{51}$ Muhammad SAW Abu Zahrah, Tarikh al-Mazahib al-Islamiyah, (Mesir. t,th), Maktabah al-Adab, h. 308 lihat juga M. Yunan Yusuf, Penafsiran Ayat-ayat Kalam Mu'tazilah menurut Asy'ariyah. h. 116

${ }_{53}^{52}$ Harun Nasution, Teologi Islam, h. 124

${ }^{53}$ Harun Nasution, Teologi Islam, h. 124

${ }^{54}$ Departemen Agama, Al-Qur'an dan terjemahnya, juz VIII, h. 216

${ }^{55}$ Departemen Agama, Al-Qur'an dan terjemahnya, juz VIII, h. 76

${ }^{56}$ Departemen Agama, Al-Qur'an dan terjemahny, juz XXIII. h. 256

${ }^{57}$ Harun Nasution, Teologi Islam, h, 125

${ }^{58}$ Yunan Yusuf, Penafsiran Ayat-ayat Kalam Mu'tazilah menurut Asy'ariyah, h. 642

${ }^{59}$ Mutasyabih, h. 642

${ }^{60}$ Harun Nasution, Teologi Islam h. 131

${ }^{61}$ Qadi Abd al-Jabbar, Syarh al-Ushul al-Khamsah,, h. 625

${ }^{62}$ Qadi Abd al-Jabbar, Syarh al-Ushul al-Khamsah,, h. 217

${ }^{63}$ Qadi Abd al-Jabbar, Syarh al-Ushul al-Khamsah, h. 226-229

${ }^{64}$ Harun Nasution, Teologi Islam, h. 159 
${ }^{65}$ Abu al-Hasan bin Ismail al-Asy'ari. al-Ibanah 'an. (Kairo: Idarat alTiba'ah al-Muniriyah, 1 th)h. 35 (selanjutnya disebut al-Ibanah) lihat juga M.Yunan Yusuf, op,cit. h. 125

${ }^{66}$ Qadi Abd al-Jabbar, Syarh al-Ushul al-Khamsah,, h. 26

${ }^{67}$ Qadi Abd al-Jabbar, Syarh al-Ushul al-Khamsah,, h. 233-266, Lihat M. Yunan Yusuf. Ibid, h. 126

${ }^{68}$ Qadi Abd al-Jabbar, Syarh al-Ushul al-Khamsah,, h. 999

${ }^{69}$ Syarh, h. 245-265 lihat M Yunan Yusuf, Penafsiran Ayat-ayat Kalam Mu'tazilah menurut Asy'ariyah, h. 127-128

70 Syarh, h. 245-265 lihat M. Yunan Yusuf, Penafsiran Ayat-ayat Kalam Mu'tazilah menurut Asy'ariyah. h. 127-128

${ }^{71}$ Abu al-Hasan bin Ismail al-Asy'ari. al-Ibanah 'an, h. 12

${ }^{72}$ Abu al-Hasan bin Ismail al-Asy'ari. al-Ibanah 'an, h. 15

${ }^{73}$ Abu al-Hasan bin Ismail al-Asy'ari. al-Ibanah 'an, h. 14

${ }^{74}$ Kitab al-Tauhid lihat juga M Yunan Yusuf, Penafsiran Ayat-ayat Kalam Mu'tazilah menurut Asy’ariyah, h. 130-131

${ }^{75}$ Abu al-Hasan bin Ismail al-Asy'ari. al-Ibanah 'an, h. 87

${ }^{76}$ Qadi Abd al-Jabbar, Syarh al-Ushul al-Khamsah,, h. 87

${ }^{77}$ Departemen Agama, Al-Qur'an dan terjemahnya, juz VIII h. 492

${ }^{78}$ Harun Nasution, Teologi Islam, h. 144

${ }^{79}$ Departemen Agama, Al-Qur'an dan terjemahnya, juz VIII, h. 495

${ }^{80}$ Departemen Agama, Al-Qur'an dan terjemahnya, juz XXIV, h.520

${ }^{81}$ Muqadimah, h.20-21

${ }^{82}$ Departemen Agama, Al-Qur'an dan terjemahnya, juz XI, h. 368

${ }^{83}$ Departemen Agama, Al-Qur'an dan terjemahnya, juz XXVI, h. 480

\section{REFRENSI}

Abu al-Hasan bin Ismai'il al-Asy'ari, al-Ibânat 'an Ushûl alDiyânah, Kairo: Idarat al-tiba'h al-Muniriyah, th

ahl al-Zaigh wa al-Bida', Kairo: Syarikh Muhasanah, 1955

al-Mushallîn, (Ed) Muhammad Saw Muhy al-Din Abd AlHamid, Kairo: Maktabah al-Nahdah al-Misriyah, 1969 Azyumardi Azra, Pergolakan Politik Islam, Dari Fundamentalisme, Modernisme hingga Post-Modernisme, Jakarta: Paramadina, 1996 
---------------, Jaringan Ulama: Timur Tengah dan Kepulauan Nusantara Abad XVII dan XVII, Bandung: Mizan, 1998

Azra, Azyumardi, Konteks Berteologi di indonesia, pengalaman islam Jakarta selatan :september 1999

Departemen Agama RI, Al-Qur'an dan Terjemahannya, Jakarta: Bumi Restu, 1977

Ferlia Citra Utama, 1996

Fachry Ali dan Bachtiar Effendi, Merambah Jalan Baru Islam:

Rekonstruksi Pemikiran Islam Masa Orde Baru, Bandung:

Mizan, 1992

Harun Nasution, Teologi Islam, Jakarta: UI Press, 1987

Mu'tazilah, Jakarta: UI Press, 1987

-, Teologi Rasional, Bandung: Mizan, 1996

Hasan Zaini, Tafsir Tematik Ayat-Ayat Kalam tafsir al-Maraghi, Jakarta: Pedoman Ilmu Jaya, 1997

Karel A. Steenbrink, Beberapa Aspek Tentang Islam di Indonesia Abad ke-19, Jakarta: Bulan Bintang, 1994

Mutaha Azhari dan Abdul Munir Mulkhan, Islam Indonesia Menatap Masa Depan, Jakarta: P3M, 1983

Al-Maturidi, Kitab al-Tauhid, Istanbul: al-Maktabah alIslamiyah, 1979 